\section{The Achilles Heel of India's High-Tech Future: World-Class Universities}

\section{Philip G. Altbach}

Philip G. Altbach is Monan professor of higher education and director of the Center for International Higher Education at Boston College.

Ten thousand American expatriates are now working in 1 India for high-tech companies. Infosys and Tata Consultancy Services, the Indian high-tech giants, will together hire and train more than 50,000 college graduates from abroad, including more than I, 000 from the United States, in the coming year. Why? Because Indian universities are not producing the quality graduates needed for the top end of the new economy. India produces many university graduates-in 2004 there were almost 700,000 degrees granted in science and engineering alone. However, with few exceptions, the institutions themselves are not of high quality. According to recent international rankings, only the Indian Institutes of Technology are noted at all, and even these are not anywhere near the top of the charts. It is not quantity, but rather quality that is lacking.

India does not spend enough on higher education-only 0.37 percent of GDP. The United States spends I.4I and the United Kingdom I.07 percent. Only countries such as Japan and Korea, where more than 80 percent of students are in largely unsubsidized private universities, approach India's low spending levels. China spends considerably more than India.

India has never seriously cared about the quality dimension of higher education. All countries are faced with the dilemma of catering to mass demand while at the same time maintaining and enhancing quality. India has consistently supported access over quality. There has been no recognition that all modern nations must have a differentiated academic system, with an elite sector at the top, mass-based and less selective institutions in the middle, and vocationally oriented postsecondary schools at the bottom. Patterns of funding, government support, and management will necessarily vary. At the top, the research universities aspire to the highest international standards of quality, follow a meritocratic code, and are ready to compete with the best universities worldwide.

\section{The Current Debate}

The tiny quality sector in Indian higher education is now being severely undermined. The new policy, introduced by the government without consulting the academic community, has been hotly contested and overwhelmingly opposed by the higher education community. The policy will increase the propor- tion of places reserved for lower-caste economically disadvantaged groups at India's small number of top institutions and will make it impossible for India to develop internationally competitive "world-class" universities. Government policies, when implemented, will mandate awarding more than half the seats in entering classes to disadvantaged groups. However laudable the goal of lessening social inequality, this policy destroys international competitiveness at the top institutions. The problem involves not only the specific reservations and the ideology behind them but also the effect on the meritocratic ethos of the research universities and other elite institutions such as the institutes of technology and management. It also leads to such absurd consequences as students with zero

\section{India does not spend enough on higher educa- tion-only 0.37 percent of GDP.}

scores on admissions tests being admitted and the creation of two distinct sets of students in the same class, with an adverse impact on teaching and learning. If India wishes to play in the international big leagues and to economically compete in a globalized world, it will need higher education institutions that prepare graduates to function in this environment, conduct advanced research that serves to advance the Indian economy, and participate at the top levels of international science and scholarship.

\section{What Is Needed}

For a start, there must be a recognition that elite higher education is necessary. A small part of India's higher education system must function at the upper international levels-as elite institutions in the best sense of the term. This does not mean that the entire system should be elite. Serving the needs of mass access and social mobility for disadvantaged groups is important, but it is not the only goal of higher education. India is now wealthy enough to support both educational goals.

Research universities everywhere have some common characteristics.

- Meritocratic values. A meritocratic university seeks to hire the most qualified faculty members, enroll the brightest students, and reward both students and staff for top performance. Fairness and consistency are central supports of academic meritocracy.

- Governmental support. Almost everywhere, research universities are public institutions. Even in the United States, where some research universities are private, they received significant government support for research. In India, only the government has the resources to support research universities. Funding must be consistent and sufficient to support a vibrant research agenda. Research universities cannot be built on the cheap. 
- Internationalization. Research universities are by their nature international institutions, linking with other similar universities in other countries and participating in the international scientific community. India has the advantage of its use of English, the world's language of science, and its possession of a large group of academics who have received training at the best universities abroad. India must take steps to broaden its international reach.

- The public good. Research universities serve the interests of society, and they require public support. They should not be forced to engage exclusively in applied research and to pay for themselves by charging high tuition and producing income from all research activities. An effective mix of basic and applied research is needed. Scholarship funds for needy but able students are also required to supplement tuition fees.

- The academic profession. Top-quality professors are central to the success of a research university. Professors must be adequately paid so that they can devote their full-time attention to academe, and so that the "best and brightest" can be attracted to the profession. There must be a stable, and competitive, academic career path that rewards merit and productivity-and punishes poor academic work by ejecting those unable to adhere to the highest standards.

- Research and teaching. Research universities emphasize and reward top-quality research, but they are also teaching institutions. Both research and teaching are necessary and contribute to the institution's goals.

- Autonomy and accountability. Research universities require a significant degree of autonomy - more than they have traditionally had in India's highly bureaucratic environment. At the same time, accountability is needed to ensure effective performance.

\section{The tiny quality sector in Indian higher education} is now being severely undermined.

The Indian Institutes of Technology are a uniquely Indian contribution to higher education. While they are not quintessential research universities, they play a key role in India's elite higher education sector. They must be supported and strengthened as institutions that support India's high-tech development.

\section{CONCLUSION}

India is truly at a turning point. If the nation is to fulfill its economic and technological potential in the 2ist century, it must have an elite and internationally competitive higher education sector at the top of a large and differentiated higher education system, with a mixture of public and private support. The elite sector requires support and recognition. It cannot afford being used as a tool for partisan political policies. World-class research-oriented universities are the spearhead of India's international competitiveness.

\section{Political Crisis at the University of Buenos Aires}

\section{Ana M. García de Fanelli}

Ana García de Fanelli is director and senior researcher in the Higher Education Department at CEDES (the Center of Study of the State and Society), Buenos Aires, Argentina, and member of CONICET (the National Council for Scientific and Technical Research). Address: Sánchez de Bustamante 27, Buenos Aires (CP 1173) Argentina. E-mail: anafan@cedes.org.

The University of Buenos Aires (UBA), Argentina's largest and most prestigious public university, has failed to gather an assembly of 236 elected professors, alumni, and students to elect a new president for the next four years. The left-wingdominated student union has been blocking the university assembly, in opposition to the candidate most likely to winAtilio Alterini, the dean of the Faculty of Law. They argue that he had held a position in the Buenos Aires city government during the last military dictatorship. During the fourth attempt to initiate the assembly, a violent fight ensued between members of the university staff unions and the students who had taken over the building. After this serious event, Alterini dropped his bid in order to unlock the political crisis. Nonetheless, the student union continued to block other attempts to hold the assembly by making new demands for greater democracy in the university. Student union activists are calling for some extreme measures, such as more student participation in decision making via a direct election of the president on a "one man, one vote" basis.

Other layers of the conflict involve ideological opposition and vested interests among the I3 UBA deans and academic authorities of the faculties, or facultades: most of the professional ones (politically conservative) support the dean of the Faculty of Law's candidacy, and the scientific faculties (politically left-wing) seek the candidacy of the prestigious molecular biologist, Alberto R. Kornblihtt. This confrontation reflects the struggle between two visions of the university-the scientific and the professional-that have paved UBA's trajectory over the last century since its foundation in I82I.

These episodes, which have been front-page news over several weeks since the beginning of April 2006, were mere symptoms of something more profound and more basic: the failures in the governance of a mega university.

\section{Professional vs. Scientific Missions}

UBA has absorbed the rapid growth of student demand since the restoration of democracy in 1983 through a policy of open admissions and cost-free education. Public resources devoted to sustain this expansion have not been able to maintain the expenditure per student. Under these financial constraints, UBA hired part-time and ad honorem (unpaid) faculty, especial- 